\section{Folkeskikk i helsetjenesten}

Herdis Alvsvåg

På sporet av et dannet helsevesen

Om nære pårørende og pasienters møte med helsevesenet. 120 s. Oslo: Akribe, 2010. Pris NOK 230

ISBN 978-82-7950-119-0

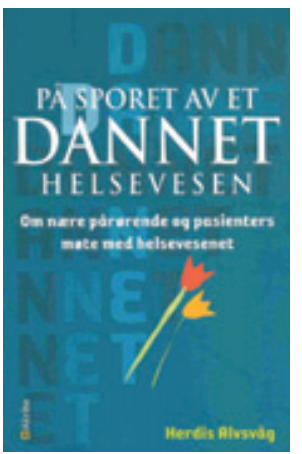

Ansatte i helsevesenet må være flinke og kunne fagene sine, men de må også være kloke - eller dannede - og forstå seg på de medmenneskene som blir pasienter og pårørende. Hvordan får vi til det? Det er det denne boken handler om. Forfatteren har lang fartstid som lærer for helsepersonell. Hun er sykepleier, lærer, sosiolog og pedagog og er nå førsteamanuensis ved Haraldsplass diakonale høgskole i Bergen. Opp igjennom livet har hun stadig skrevet bøker og artikler. Denne utgivelsen bygger derfor på lang erfaring og i tillegg på intervjuer med pasienter og pårørende. Den er et ledd i et forskningsprosjekt med samme tittel. Boken er av den grunn en vitenskapelig monografi og ikke bare «en synsebok».

I åtte korte kapitler drøfter forfatteren de forskjellige sidene ved våre yrker som helsepersonell. Hun tar utgangspunkt i filosofi, etikk og i Aristoteles' tre grunnprinsipper: Episteme $=$ viten, kunnskap, Techne $=$ ferdigheter, håndlag, kyndighet og Phronesis = klokskap, visdom. Vi trenger klokskap for å bruke viten og ferdigheter på en god måte, og klokskap er nettopp dannelse. I de enkelte kapitlene diskuterer hun kyndig omsorg, engasjement og ansvar, respekt og verdighet, forståelse og mot og humør og humor. I det siste kapitlet beskriver Alvsvåg de forskjellige kunnskapsformene og læringsarenaene og viser at disse arenaene er forskjellige, men likeverdige. De er alle viktige, og målet er et dannet helsepersonell. Dannelse er summen av de gode egenskapene, og kanskje er dannelse det samme som det Aristoteles tenkte med «phronesis». Dannelse er derfor et grunnleggende og viktig begrep som stiller større og mer grunnleggende krav enn bare det enkle ordet «folkeskikk».
Forfatteren skriver godt, og hun bygger på et helt livs erfaring som lærer og forsker. Hun er belest, og man finner sitater fra og henvisninger til de kjente pedagogene og filosofene på dette feltet. Det er også med mange pasientfortellinger fra intervjuene, og hun avslutter kapitlene med en serie refleksjonsspørsmål som leseren må gruble over. Målgruppen er først og fremst helsepersonell, særlig sykepleiere og leger, men budskapet er viktig for alle «menneskeyrkene» i helsetjenesten, skolen, trygdevesenet, politiet og andre. Litteraturlisten og stikkordregisteret er utmerket.

Jeg synes dette er en god og viktig bok. Den kunne kanskje vært litt kortere og strammere, men temaet trenger også både fordypelse og bredde. Jeg vil derfor anbefale den både for studenter og lærere i helsefagene. De blir ofte druknet i kunnskaper og teknikk, og det er fort gjort å glemme dannelsen og at det er våre medmennesker som er pasienter og pårørende.

\section{Peter F. Hjort}

Blommenholm

\section{Kampen for livet}

Runar Vincents Johannessen Tilbake til livet

175 s. Oslo: Aschehoug, 2010. Pris NOK 349 ISBN 978-82-03-23719-5

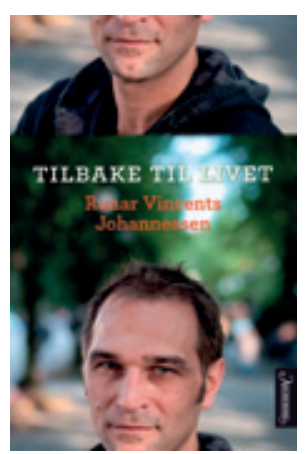

Forfatteren var en ung og lovende medisinstudent da han knapt 25 år gammel ble slått ned en natt på et utested i Oslo i mai 1993. Begge var beruset, og den andres knyttneveslag traff ham i pannen, så hardt at pannelappen

i hjernen ble skadet. Bakhodet knallet i asfalten, og det førte til at balansesenteret på venstre side ble skadet, og han blødde fra begge øregangene. Han ble plukket opp av politiet og først kjørt til Oslo legevakt og så flyttet til legevakten i Bærum. Her falt han i koma og ble overført til nevrokirurgisk avdeling ved Rikshospitalet. Han ble ope- rert og våknet opp etter fem uker i koma uten å kunne stå, gå, spise, snakke eller huske noe som helst. Langsomt kom han seg og ble sendt tre måneder på Sunnaas sykehus. Han kom seg såpass etter hvert at han ble sendt hjem til foreldrene, og siden høsten 1994 har han bodd alene. Så fulgte ti treningsår: rullestol, gåstol, krykker, gåing og til slutt jogging. Han prøvde forgjeves å lære fotografering. Et datakurs ble redningen. Etter tre år hadde han lært seg webdesign og fikk en deltidsjobb knyttet til Internett.

Det har nå gått 17 år, og han har skrevet denne boken om kampen for livet, ikke bare for eksistensen. Oppskriften har vært aldri å gi seg. Siden hukommelsen var borte, måtte han begynne på nytt, dag etter dag. En ufattelig stahet og verdighet drev ham frem: Målet var et uavhengig liv. Da han ble skrevet ut fra Sunnaas, var det to alternativer: sykehjem resten av livet eller kampen for et selvstendig liv i sin egen leilighet. Han visste at han var en intelligent stribukk, og stoltheten drev ham frem - dag etter dag og år etter år. Han gjennomførte et stort datakurs og fikk til slutt jobb i TV2. Og nå, etter 17 år, føler han seg trygg. Han kommer seg stadig, men glemmer lett, og påpasselighet og pliktfølelse er veien han må gå.

I disse årene har han hatt avgjørende hjelp og støtte av et stort og godt sosialt nettverk, først og fremst av familien og trofaste venner, særlig rappervenner fra musikken. Han vet at oppskriften er å være et godt og hjelpsomt menneske som tenker mer på andre enn på seg selv. Det er viktig å være flink, men det er langt viktigere å være god. Slik har disse 17 årene gått, og han føler seg stadig på vei opp og frem. Han drømmer nok om kjærlighet, men foreløpig må det holde med vennskap og trofasthet.

Denne boken har han skrevet for å hjelpe seg selv til å finne sin egen vei og sitt eget liv. Han opplever at han har hatt en utrolig fremgang, særlig de siste fem årene. Boken har hjulpet ham til å se veien fra de første årenes totale fortvilelse - til et målbevisst, personlig og eget liv. Og han har også tenkt at hans kamp kan hjelpe andre som kjemper seg frem etter skade og sykdom, til tross for at alle er forskjellige.

Jeg tror at han har rett i dette, og derfor har jeg lest med interesse og engasjement, og jeg er blitt dypt imponert. Boken er disponert slik at den følger tiden gjennom alle de 17 årene. Den er delt opp i korte kapitler som gjør det lett å følge med. Språket er 